http://kitaibelia.unideb.hu/

ISSN 2064-4507 (Online) • ISSN 1219-9672 (Print)

(C) 2015, Department of Botany, University of Debrecen, Hungary

20 (2): 286-299.; 2015

DOI: $10.17542 /$ kit.20.286

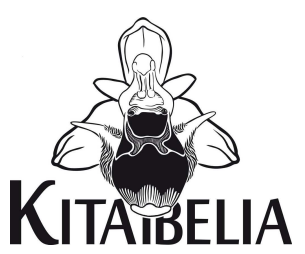

\title{
Növényi jellegek és alkalmazásuk növényökológiai kutatásokban I.: Történeti áttekintés, jelleg típusok, módszertan és adatbázisok
}

\author{
E. VojTKó Anna* \& LUKÁcS Balázs András \\ Magyar Tudományos Akadémia, Ökológiai Kutatóközpont, Tisza-kutató Osztály, H-4026, Debrecen, Bem tér 18/C; \\ *vojtko.anna@okologia.mta.hu

\section{Plant functional traits and their application in ecological research I.: History, traits, methodologies and databases}

\begin{abstract}
The importance of studies based on plant functional traits is indicated by the huge number of papers (more than 5000) published in the last 15 years in this topic. In community ecology the recent trend of studying organisms on the functional- rather than on the taxonomic level is quite significant. In this review we attempted to summarise the applicability of functional plant traits commonly used in ecological studies. We discussed the levels of functional categorisation, described the different plant strategies based on functional traits and emphasised the usage of standardised measurements. The most outstanding trait databases are introduced here, showing their availability, content and specialities. This review is intended as an introduction to the topic and can later be completed by papers elaborating on how plant functional traits are used in theoretical and applied plant ecology.
\end{abstract}

Keywords: functional ecology, growth-form, LEDA, life-form, plant strategies, SLA, TRY

Összefoglalás: A növényi funkcionális jellegek kutatásának aktualitását mi sem jelzi jobban, mint az a több mint 5000 publikáció, mely az utóbbi 15 évben megjelent a témában. A közösségi ökológia számára ma már nélkülözhetetlen a fajok szintjén túlmutató funkcionális csoportok alkalmazása, ahol a növényeket taxonómiai minőségük helyett funkcionális jellegeik alapján vizsgálják. Jelen dolgozatban bemutatjuk a növényökológiában leggyakrabban alkalmazott növényi jellegeket, típusaikat valamint az általuk meghatározott növényi stratégiákat. Szót ejtünk a jellegek egységes mérésének módszertanáról, illetve bemutatjuk a legfontosabb jellegadatbázisokat, és azok alkalmazási lehetôségeit. Jelen dolgozatot a téma bevezetésének szánjuk, amit később olyan írások követhetnek, amelyek részletesen foglalkoznak a funkcionális jellegek gyakorlatban történő alkalmazásának lehetőségeivel.

Kulcsszavak: életforma, fajlagos levélfelület, funkcionális ökológia, LEDA, növekedési forma, növényi stratégiák, TRY

\section{Bevezetés}

A közösségi ökológia alapvető célja, a térben és időben együtt élő fajok, az élőlényközösségek szerveződési szabályainak kutatása (MACARTHUR 1972). Az 1960-as évektől az ökológiai kutatások egy jelentős része a fajok egyedeinek és populációinak dinamikai jellemzőit igyekezett feltárni, és a kapott eredményekből általános következtetéseket levonni. Ez időben születtek meg olyan alapvető közösségszerveződési és diverzitási modellek és fogalmak, mint a 
neutrális- és niche elmélet, vagy a különböző diverzitási indexek. Azt azonban meg kell említenünk, hogy ezeknek a vizsgálatoknak az alapjai a fajok voltak, a közösségeket pedig többnyire (de nem kizárólagosan) az abban előforduló taxonok faji hovatartozásával, nem pedig azok ökológiai szerepével jellemezték (florisztikai-taxonómiai megközelítés). Ez utóbbi megközelítés az ökológiai információtartalom jelentős csökkenését okozta (FUKAMI et al. 2005), valamint bizonyos problémafelvetések megoldására már nem volt megfelelő. A fajok ökológiai szerepének (funkcionális megközelítés) értékelése nélkül kevés az információtartalma annak, hogy egy adott faj adott helyen előfordul vagy sem, illetve magas vagy alacsonyabb az adott közösség diverzitása. A világ különböző részein végzett, csupán az élőlények faji hovatartozását figyelembe vevő vizsgálatok eredményeinek összehasonlítása is komoly nehézségekbe ütközött. Azonban, ha figyelembe vesszük a fajok objektíven mérhető jellegeit, amelyeken keresztül ökológiai szerepükre is következtethetünk, ezek az összehasonlítások kivitelezhetővé válnak (WESTOBY 1998).

WARMING (1909) úgy nyilatkozott: „távol vagyunk még attól, hogy a számtalan növényi forma ökológiai magyarázatát megadjuk". Az utóbbi évtizedekben egyre intenzívebben felmerülő és egyre nagyobb problémát okozó jelenségek (például idegenhonos fajok inváziója, klímaváltozás, élőhelyek zavarása) a közösségek szerkezetében igen gyors és jelentős változásokat idéznek elő. Így a funkcionális ökológiának nagy szerepe van és lesz is abban, hogy ezeknek a változásoknak az alapvető okait megérthessük. Előtérbe kerültek továbbá az ökoszisztémák szerepét, funkcióját - illetve magukat az ökoszisztémákat, mint az emberi jóléthez elengedhetetlen szolgáltatást nyújtó rendszert - bemutató elméletek és ideológiák. A közösségekben történő változások kiváltó okainak vagy az ökoszisztémák alapvető működési sajátságainak értelmezésére ad lehetőséget a növényi funkcionális típusok és csoportok megalkotása, illetve eszközként a funkcionális jellegek használata.

Az utóbbi 15 évben a funkcionális alapon létrejött publikációk számának egyre intenzívebb növekedését figyelhetjük meg (lásd még például CADOTTE et al. 2011). A Google Scholar keresőprogramban a „plant trait” szavakra rákeresve a 2000-es éveket megelőzően mindössze 534 találatot kapunk. Ez egészen elenyésző ahhoz az 5330 publikációhoz képest, amely az utóbbi 15 év során jelent meg a nemzetközi szakirodalomban. Éves lebontásban a témában megjelent tanulmányok száma meredeken emelkedő görbét ír le (1. ábra).

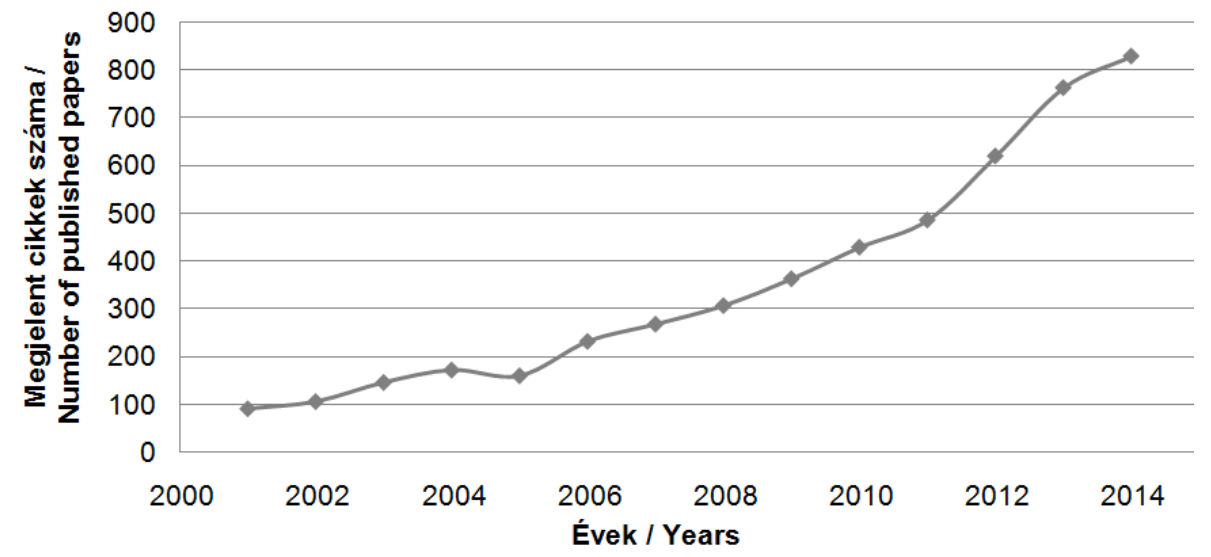

1. ábra A Google Scholar találatai a „plant trait” keresőszavakra az utóbbi 15 évben.

Fig. 1. Papers found on Google Scholar using „plant trait” as keyword in the last 15 years.

Ez a látványos trend késztetett bennünket arra, hogy megkíséreljük összegezni a funkcionális jellegeken alapuló kutatások történetét és az ezekben rejlő lehetőségeket. Míg nemzet- 
közi tudományos fórumokon (ide értve magyar szerzők ilyen témájú nemzetközi publikációit is, például FENESI \& BOTTA-DUKÁT 2012, ALBERT et al. 2013, RUPRECHT et al. 2014, KELEMEN et al. 2015 stb.) növekedés figyelhető meg a növényi jellegek felhasználását tekintve, a gyakorlati szakemberek által preferált magyar nyelvü szakirodalomban kevés publikációt közöltek ebben a témában. Hazai, magyar nyelvü folyóiratban is jelent már meg olyan, növényi tulajdonságokkal, adatbázisokkal és ezek növényökológiai kutatásokban betöltött szerepével foglalkozó publikáció (CSECSERITS et al. 2009), mely igen körültekintően mutatja be a témakört, ám mindezek ellenére úgy érezzük, a téma sokszínűsége és az utóbbi években tapasztalható dinamikus fejlődése miatt szükség van olyan nagyobb terjedelmű, részletes összegzésre, mely a hazai kutatók számára is hasznos és gondolatébresztő lehet.

A növényi jellegeken alapuló funkcionális megközelítés fiatal tudományágnak tekinthető és meglehetősen bonyolult, ezért a témával kapcsolatos definíciók és terminus technicusok értelmezése szerteágazó és sok esetben még nem kiforrott (lásd MASON et al. 2005, VILLÉGER et al. 2008). A funkcionális alapon történő csoportosítás gyakorlati használhatóságával kapcsolatban több kérdés is felmerülhet, például mely növényi jellegek lehetnek prediktorai a fajok abundanciájának vagy indikátorai a vegetációs változásoknak, az élőhelyek leromlásának? Milyen filogenetikai háttere van a funkcionális jellegeknek? A témával kapcsolatos publikációk száma nagy és tartalmuk igen változatos, nem lehet azt egy cikkben összegezni, ezért ezt a szerteágazó témát több részletben tervezzük összefoglalni.

Az első részben a növényi tulajdonságokkal kapcsolatos korai elméleteket, előzményeket mutatjuk be. Definiáljuk a témához kapcsolódó fogalmakat és bemutatjuk a jelenleg általánosan alkalmazott növényi jellegeket, jellegcsoportokat. Részletezzük a jellegek mérésének módszertanát, végül pedig bemutatjuk a ma létező nagyobb nemzetközi jellegadatbázisokat. A további részekben igyekszünk majd a növényi jellegeken alapuló tanulmányokat összegezni, bemutatva azokat a fóbb ökológiai kérdésköröket, melyek megválaszolására eredményesen alkalmazhatók.

Jelen esetben igyekeztünk elkerülni a CSECSERITS et al. (2009) által már bemutatott aspektusok pontos ismétlését. Bár számos, már ott részletezett fejezetet is feldolgoztunk, arra törekedtünk, hogy a lehető legfrissebb szakirodalmi példákon keresztül olyan anyagot gyüjtsünk össze, mely segíti a botanikus és növényökológus szakemberek tájékozódását ebben a témakörben.

\section{Tárgyalás}

Funkcionális csoportosítás

Az alapvető emberi természethez hozzátartozik az a törekvés, hogy a környezetünkben található élőlényeket, tárgyakat osztályozni próbáljuk. Az ökológusoknak jutott az a feladat, hogy kísérleteik eredménye alapján modellezzék, számszerűsítsék az élőlények tulajdonságait és viselkedését vagy az élőlényközösségek szerveződési szabályait. Ehhez sok esetben szükség van mesterségesen, ideális esetben objektíven képzett kategóriákra.

A (1) guild, (2) életforma és növekedési forma, (3) funkcionális típus és csoport, (4) növényi jelleg és tulajdonság, illetve (5) növényi stratégia fogalmak a témához szorosan kapcsolódó egymást meghatározó kifejezések, melyek a funkcionális csoportosítás különböző szintjeire utalnak.

\section{Guildek}

SCHIMPER (1903) 'Genossenschaften' kifejezése szorosan kapcsolódik a funkcionális csoportosításhoz. Azok a fajok alkotnak egy guildet, amelyek ugyanazokat a forrásokat ugyanazzal a 
módszerrel hasznosítják. Ha növényekre alkalmazzuk őket, a fogalom bizonyos esetekben megfeleltethető a funkcionális csoporttal vagy funkcionális típussal (lásd lentebb).

\section{Életformák és növekedési formák}

Az első tudományosan megalapozott növényi életforma típusokat (tulajdonképpeni funkciós csoportokat) THEOPHRASZTOSZ (kb. i.e. 300) alkotta meg, aki természettudományokban és filozófiában is jeleskedő Arisztotelész-tanítvány volt. Olyan rendszert állított fel, mely a száruk magassága és sűrüsége szerint sorolja típusokban a növényeket, így megkülönböztetünk fákat, cserjéket és lágyszárúakat (füveket). Talán ezek az első, ma is használt olyan növényi attribútumok, amelyek segítségével növényi jellegeken alapuló életformakategóriákat hoztak létre. Ezt az osztályozást és a növényi tulajdonságok életformákon alapuló rendszerét a 20. században felvirágzó természettudományos érdeklődésű tudósok fejlesztették tovább. Köztük volt Eugenius Warming, dán botanikus, akit sokszor „a növényökológia atyja"-ként is emlegetnek, és akinek számos növényfaj leírásán túl Izland és Grönland biogeográfiai felmérését, az első növényökológia tankönyvet, illetve az első növényi életforma kategóriákat is köszönhetjük (WARMING 1884). Az ő életforma-rendszerét fejlesztette tovább tanítványa, Christien Raunkiær, aki az általa kidolgozott rendszerben az áttelelő szervek helyzete alapján osztályozta a növényeket (RAUNKIÆR 1934), így alapozva meg (később további számos altípussal kiegészítve) a ma is használatos életformatípusokat (Phanerophyta, Chamaephyta, Hemikryptophyta, Kryptophyta, Geophyta, Helophyta, Hydrophyta, Therophyta, Hemitherophyta, Aerophyta, Epiphyta).

\section{Funkcionális típusok és funkcionális csoportok (Plant functional type, PFT)}

Néhány kivételtől eltekintve funkcionális értelemben a csoportot és típust szinonimaként kezelik a szakirodalomban (REICH et al. 2003). Egy funkcionális típusba tartoznak azok a fajok, melyek hasonló környezeti hatásokra hasonló jelleg eloszlásokkal válaszolnak, valamint hasonló ökológiai hatásuk van (TILMAN 2001). Ehhez jelentésben szorosan kapcsolódik a „növényi funkcionális válasz-típusok" kifejezés (plant functional response type, LoUAULT et al. 2005), amely a környezetre hasonló választ adó növényeket sorolja egy csoportba. A funkcionális típusokat növényi funkcionális jellegek (lásd lentebb) alapján lehet meghatározni, így a gyakran egymáshoz kapcsolódó jellegek tulajdonképpen jelleg-csoportokat alkotnak (trait assemblages, trait syndromes, ALBERT et al. 2010). Azonban a vizsgált jellegek száma nem határozza meg egyértelműen a képezhető funkcionális csoportok számát, hiszen például a kategorikus jellegek esetében minden egyes kategória külön funkcionális csoportnak tekinthető, illetve a különböző jellegek más-más kombinációi szintén alkothatnak külön funkciós csoportot.

\section{Növényi jellegek és tulajdonságok}

A biológiában „jelleg”-nek nevezzük az élőlények jól körülhatárolható, egyedeken mérhető sajátosságait, melyek alkalmasak a faji szintű összehasonlításokra (McGILL et al. 2006). A biológiai jellegek egy szűkebb csoportját képezik a funkcionális jellegek, melyek esetében többnyire olyan mérhető fenotípusos tulajdonságokról van szó, melyek meghatározható kapcsolatban állnak valamilyen biológiai funkcióval (GAUCHERAND \& LAVOREL 2007). Ezek a fenotípusos jellegek képesek direkt vagy indirekt módon befolyásolni az egyed fitneszét (ALBERT et al. 2010) valamilyen biokémiai, élettani, morfológiai, fejlődéstani vagy viselkedésbeli mechanizmuson keresztül (GEBER \& GRIFFEN 2003). Egy gondolattá összefüzve: a funkcionális jellegek olyan egyedi szinten mérhetô, a sejttól egészen a szervezet szintjéig terjedô morfológiai, fiziológiai vagy fenológiai tulajdonságok, melyek direkt vagy indirekt módon befolyásolják az egyed fitneszét, hatással vannak a teljesitőképességet meghatározó három fö tényezöre 
(növekedésre, szaporodásra és túlélésre), ám nem vonatkoznak a türőképességi és elterjedési jellemzôkre illetve nem értelmezhetőek magasabb szerveződési szinteken (VIOLLE et al. 2007).

CSECSERITS et al. (2009) javaslatának megfelelően a magyar nyelvben „növényi jelleg”-nek fordítjuk az angol „plant trait” kifejezést, míg a „növényi tulajdonságok” a „plant characteristics” megfelelője. Az utóbbi tágabban értendő fogalom, mely vonatkozhat a növény és a környezet kapcsolatára, a fajok ökológiai igényeire, elterjedésére is. Funkcionális attribútumnak (,functional attribute") nevezzük a kategoriális skálán mérhető funkcionális jellegek egyes kategóriáit (LAVOREL et al. 1997, VIOLLE et al. 2007, VAN DER MAAREL \& FRANKLIN 2013).

A növényi jellegeket két csoportba soroljuk attól függően, hogy az adott jelleg mérése mennyire egyszerúen kivitelezhető ill. közvetlenül kapcsolódik-e az adott faj ökológiai funkciójához. A „soft-trait” jellegek könnyen mérhetők, ám nem mindig kapcsolódnak közvetlenül biológiai funkcióhoz (pl. a növény magassága, fitomasszája, fajlagos levélfelület). Ezzel szemben az általában nehezen mérhető ún. „hard-trait” jellegek (pl. fotoszintetikus aktivitás, avar bomlási sajátosságai, földalatti szervek jellegei) nehezen mérhetőek viszont közvetlen funkcionális szerepük van (LAVOREL \& GARNIER 2002). Bár ezt a felosztást általánosan használják, számos szerző nem javasolja a "soft-hard” megkülönböztetést, mivel véleményük szerint ez nem minden esetben kellően megalapozott vagy objektív (VIOLLE et al. 2007, GILLISON 2013).

1. táblázat. A leggyakrabban használt növényi funkcionális jellegek és magyarázatuk anatómiai helyzetük szerint. Röv. - nemzetközileg használt rövidítések; kat. - kategóriák; Skálák: N - nominális, 0 ordinális, A - arány (PÉREZ-HARGUINDEGUY et al. 2013 alapján kiegészítve).

Table 1. Frequently used plant functional traits and their explanations according to their anatomical position. Abbr. - internationally used abbreviations; cat. - categories; Scales: N - nominal, 0 - ordinal, R ratio (extended based on PÉREZ-HARGUINDEGUY et al. 2013).

\begin{tabular}{|c|c|c|c|c|c|}
\hline & Név / Name & $\begin{array}{l}\text { Röv. / } \\
\text { Abbr. }\end{array}$ & $\begin{array}{c}\text { Mértékegység / } \\
\text { Unit }\end{array}$ & $\begin{array}{c}\text { Skála / } \\
\text { Scale }\end{array}$ & $\begin{array}{l}\text { Magyarázat / } \\
\text { Explanation }\end{array}$ \\
\hline \multirow{8}{*}{ 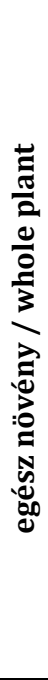 } & $\begin{array}{l}\text { növekedési forma / } \\
\text { growth form }\end{array}$ & & kat. / cat. & $\mathrm{N}$ & $\begin{array}{l}\text { a vegetációs (funkcionális) } \\
\text { periódus kedvező idősza- } \\
\text { kában kialakuló habitus }\end{array}$ \\
\hline & életforma / life form & & kat. / cat. & $\mathrm{N}$ & $\begin{array}{l}\text { Raunkiaer-féle kategóriák } \\
\text { (kedvezőtlen időszakok } \\
\text { átvészelésére kialakult } \\
\text { adaptáció) }\end{array}$ \\
\hline & magasság / plant height & & $\mathrm{m}$ & $\mathrm{A} / \mathrm{R}$ & maximum hajtásmagasság \\
\hline & klonalitás / clonality & & kat. / cat. & 0 & klonális szaporodás módja \\
\hline & $\begin{array}{l}\text { sarjadási képesség / } \\
\text { resprouting capacity }\end{array}$ & & kat. / cat. & 0 & $\begin{array}{l}\text { a földfeletti biomassza } \\
\text { eltávolítása után képes-e } \\
\text { új hajtást hozni }\end{array}$ \\
\hline & tövisesség / spinescence & & kat. / cat. & 0 & $\begin{array}{l}\text { milyen mértékben borítják } \\
\text { tövisek vagy tüskék }\end{array}$ \\
\hline & $\begin{array}{l}\text { gyúlékonyság / } \\
\text { flammability }\end{array}$ & & kat. / cat. & 0 & $\begin{array}{l}\text { milyen gyorsan kap lángra } \\
\text { és ég el a növényi anyag }\end{array}$ \\
\hline & $\begin{array}{l}\text { relatív növekedési ráta / } \\
\text { relative growth rate }\end{array}$ & RGR & $\%$ & $\mathrm{~A} / \mathrm{R}$ & $\begin{array}{l}\text { t1 és t2 időpillanat közti } \\
\text { száraz tömeg gyarapodás }\end{array}$ \\
\hline \multirow{4}{*}{ 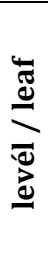 } & $\begin{array}{l}\text { fajlagos levélfelület / } \\
\text { specific leaf area }\end{array}$ & SLA & $\begin{array}{c}\mathrm{m}^{2} / \mathrm{kg} \\
\mathrm{mm}^{2} / \mathrm{mg}\end{array}$ & $\mathrm{A} / \mathrm{R}$ & $\begin{array}{l}\text { levél felülete / levél száraz } \\
\text { tömege }\end{array}$ \\
\hline & levélfelület / leaf area & LA & $\mathrm{mm} 2$ & $\mathrm{~A} / \mathrm{R}$ & \\
\hline & $\begin{array}{l}\text { levél szárazanyag tartalom / } \\
\text { leaf dry matter content }\end{array}$ & LDMC & $\mathrm{mg} / \mathrm{g}$ & $\mathrm{A} / \mathrm{R}$ & $\begin{array}{l}\text { levél száraz tömege / } \\
\text { nedves tömege }\end{array}$ \\
\hline & $\begin{array}{l}\text { levél N koncentráció / } \\
\text { leaf N concentration }\end{array}$ & LNC & $\mathrm{mg} / \mathrm{g}, \%$ & $\mathrm{~A} / \mathrm{R}$ & $\begin{array}{l}\text { levél teljes } \mathrm{N} \text { tartalma / } \\
\text { levél száraz tömege }\end{array}$ \\
\hline
\end{tabular}


E. VoJTKó \& LUKÁCS (2015) - Kitaibelia 20 (2): 286-299.

\begin{tabular}{|c|c|c|c|c|c|}
\hline & Név / Name & $\begin{array}{l}\text { Röv. / } \\
\text { Abbr. }\end{array}$ & $\begin{array}{c}\text { Mértékegység / } \\
\text { Unit }\end{array}$ & $\begin{array}{c}\text { Skála / } \\
\text { Scale }\end{array}$ & $\begin{array}{c}\text { Magyarázat / } \\
\text { Explanation }\end{array}$ \\
\hline \multirow{5}{*}{ 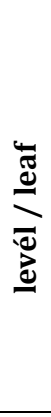 } & $\begin{array}{l}\text { levél P koncentráció / } \\
\text { leaf P concentration }\end{array}$ & LPC & $\mathrm{mg} / \mathrm{g}, \%$ & $\mathrm{~A} / \mathrm{R}$ & $\begin{array}{l}\text { levél teljes P tartalma / } \\
\text { levél száraz tömege }\end{array}$ \\
\hline & $\begin{array}{l}\text { fotoszintézis típusa / } \\
\text { photosythetic pathway }\end{array}$ & & kat. / cat. & $\mathrm{N}$ & C3, C4, CAM \\
\hline & $\begin{array}{l}\text { levél élettartam / } \\
\text { leaf lifespan }\end{array}$ & LL & hónap / month & $\mathrm{A} / \mathrm{R}$ & $\begin{array}{l}\text { időtartam, amíg egy levél } \\
\text { élettanilag aktív }\end{array}$ \\
\hline & $\begin{array}{l}\text { fogyaszthatóság / } \\
\text { leaf palatability }\end{array}$ & & kat. / cat. & 0 & $\begin{array}{l}\text { növényevő állatok } \\
\text { preferenciája }\end{array}$ \\
\hline & $\begin{array}{l}\text { avar lebomlási ráta / } \\
\text { litter decomposability rate }\end{array}$ & & $\%$ & $\mathrm{~A} / \mathrm{R}$ & $\begin{array}{l}\text { az avar t1 és t2 időpillanat } \\
\text { közti száraz tömeg } \\
\text { csökkenése }\end{array}$ \\
\hline \multirow{3}{*}{ 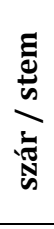 } & $\begin{array}{l}\text { fajlagos szársűrűség / } \\
\text { stem specific density }\end{array}$ & SSD & $\mathrm{mg} / \mathrm{mm}^{3}$ & A / R & $\begin{array}{l}\text { szárdarab száraz tömege / } \\
\text { térfogata friss állapotban }\end{array}$ \\
\hline & $\begin{array}{l}\text { ág szárazanyag tartalom / } \\
\text { twig dry matter content }\end{array}$ & TDMC & $\mathrm{mg} / \mathrm{g}$ & $\mathrm{A} / \mathrm{R}$ & $\begin{array}{l}\text { ág száraz tömege / } \\
\text { nedves tömege }\end{array}$ \\
\hline & $\begin{array}{l}\text { kéregvastagság / } \\
\text { bark thickness }\end{array}$ & & $\mathrm{mm}$ & $\mathrm{A} / \mathrm{R}$ & $\begin{array}{l}\text { fás szárúak harmadlagos } \\
\text { bőrszövetének vastagsága }\end{array}$ \\
\hline \multirow{3}{*}{ 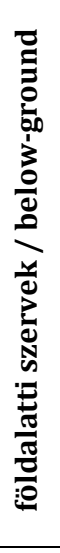 } & $\begin{array}{l}\text { fajlagos gyökérhosszúság / } \\
\text { specific root length }\end{array}$ & SRL & $\mathrm{m} / \mathrm{g}$ & $\mathrm{A} / \mathrm{R}$ & $\begin{array}{l}\text { gyökérszőrökkel } \\
\text { rendelkező gyökerek össz- } \\
\text { hosszúsága / össz-száraz } \\
\text { tömege }\end{array}$ \\
\hline & $\begin{array}{l}\text { gyökérátmérő / } \\
\text { fine root diameter }\end{array}$ & & $\mathrm{mm}$ & $\mathrm{A} / \mathrm{R}$ & $\begin{array}{l}\text { gyökérszőrökkel } \\
\text { rendelkező gyökerek } \\
\text { átmérője }\end{array}$ \\
\hline & $\begin{array}{l}\text { tápanyagfelvételi stratégia / } \\
\text { nutrient uptake strategy }\end{array}$ & & kat. / cat. & $\mathrm{N}$ & $\begin{array}{l}\text { tápanyagfelvételt segítő } \\
\text { interspecifikus } \\
\text { kölcsönhatások (pl. } \\
\text { szimbiózis N2 megkötő } \\
\text { baktériumokkal vagy } \\
\text { mikorrhiza gombákkal, } \\
\text { parazitizmus, } \\
\text { rovarfogyasztás) }\end{array}$ \\
\hline \multirow{6}{*}{ 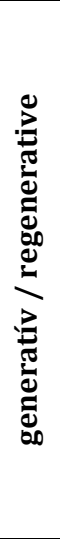 } & $\begin{array}{l}\text { terjedés típusa / } \\
\text { dispersal mode }\end{array}$ & & kat. / cat. & $\mathrm{N}$ & $\begin{array}{l}\text { a propagulum } \\
\text { terjedésének módja, a } \\
\text { terjesztő ágens típusa } \\
\text { szerint }\end{array}$ \\
\hline & magtömeg / seed weight & SW & $\mathrm{mg}$ & $\mathrm{A} / \mathrm{R}$ & egy db mag száraz tömege \\
\hline & $\begin{array}{l}\text { ezermagtömeg / thousand } \\
\text { seed weight }\end{array}$ & TSW & g & A / R & $\begin{array}{l}\text { ezer db mag száraz } \\
\text { tömege }\end{array}$ \\
\hline & $\begin{array}{l}\text { virágzás kezdete / } \\
\text { flowering start }\end{array}$ & & hónap / month & 0 & \\
\hline & $\begin{array}{l}\text { virágzás időtartama / } \\
\text { flowering period }\end{array}$ & & hónap / month & $\mathrm{A} / \mathrm{R}$ & \\
\hline & $\begin{array}{l}\text { megporzás típusa / } \\
\text { pollen vector }\end{array}$ & & kat. / cat. & $\mathrm{N}$ & $\begin{array}{l}\text { a megporzás módja (pl. } \\
\text { geitono- és kleisztogámia, } \\
\text { vektor által stb.) }\end{array}$ \\
\hline
\end{tabular}

A jellegeket osztályozhatjuk statisztikai értelemben aszerint, hogy mennyiségiek (például hajtásmagasság) vagy minőségiek (például életforma típus), illetve a mérési skála szerint lehetnek nominális (például életforma), ordinális (például gyúlékonyság) vagy arány (például levélfelület) skálán értelmezhetők. Didaktikai szempontból az is célravezető, ha 
anatómiai helyzetüknek megfelelően csoportosítjuk őket: (i) egész növényre vonatkozó jellegek, (ii) levéljellegek, (iii) szárjellegek, (iv) földalatti szervek jellegei és (v) generatív jellegek (PÉREZ-HARGUINDEGUY et al. 2013, lásd még 1. táblázat).

A szakirodalom megkülönböztet hatás (effect) és válasz (response) jellegeket (GILLISON 2013), aszerint, hogy környezeti tényezőkben bekövetkező változások indikátoraiként (válasz), vagy az ökológiai változásokat előidéző jellegként (hatás) tekintenek-e az adott növényi jellegre (részletesen lásd LAVOREL et al. 2007, GARNIER et al. 2007). Egy adott jelleg különböző kontextusban viselkedhet hatás-, ill. válasz-jellegként is, azaz mindig az adott kutatás dönti el, hogy egy bizonyos jelleg milyen szerepet játszik a vizsgálatban.

A növényi funkcionális jellegeket sok esetben valamilyen környezeti változó által meghatározott gradiens mentén vizsgálják. A 2. táblázat példákat mutat arra, hogy mely jelleg mely környezeti faktorral hozható összefüggésbe.

2. táblázat Néhány fontosabb környezeti változó és a velük összefüggésbe hozható növényi funkcionális jellegek (LAVOREL \& GARNIER 2002 alapján kiegészítve).

Table 2. Environmental factors and related plant functional traits (extended based on LAVOREL \& GARNIER 2002).

\begin{tabular}{|c|c|c|}
\hline $\begin{array}{l}\text { Környezeti tényező / } \\
\text { Environmental factor }\end{array}$ & $\begin{array}{c}\text { Növényi funkcionális jelleg / } \\
\text { plant functional trait }\end{array}$ & Példák / Examples \\
\hline $\begin{array}{l}\text { klíma / } \\
\text { climate }\end{array}$ & $\begin{array}{l}\text { életforma / life form } \\
\text { levéljellegek / leaf traits } \\
\text { genom mérete / genom size }\end{array}$ & $\begin{array}{l}\text { MCGILLIVRAY \& GRIME (1995), } \\
\text { PAVÓN et al. (2000), } \\
\text { NIINEMETS (2001), REICH \& } \\
\text { OLEKSYN (2004) }\end{array}$ \\
\hline $\begin{array}{l}\text { talaj } \\
\text { tápanyagtartalma / } \\
\text { soil nurtient content }\end{array}$ & $\begin{array}{l}\text { fajlagos levélfelület / specific leaf area } \\
\text { levél kémiai összetétele / leaf chemical } \\
\text { composition }\end{array}$ & $\begin{array}{l}\text { CUNNINGHAM et al. (1999), } \\
\text { POORTER \& DE JONG (1999), } \\
\text { ORDOÑEZ et al. (2009) }\end{array}$ \\
\hline $\begin{array}{l}\mathrm{CO}_{2} \text { koncentráció / } \\
\mathrm{CO}_{2} \text { concentration }\end{array}$ & $\begin{array}{l}\text { életciklus / life cycle } \\
\text { relatív növekedési ráta / relative growth rate } \\
\text { fotoszintézis típusa / photosinthetic pathway }\end{array}$ & $\begin{array}{l}\text { POORTER et al. (1996), } \\
\text { KIRSCHBAUM (2011) }\end{array}$ \\
\hline $\begin{array}{l}\text { árnyékoltság / } \\
\text { shading }\end{array}$ & $\begin{array}{l}\text { relatív növekedési ráta / relative growth rate } \\
\text { levél- és gyökérmorfológia / leaf and root } \\
\text { morphology } \\
\text { magtömeg / seed mass }\end{array}$ & $\begin{array}{l}\text { LEISHMAN \& WESTOBY (1994), } \\
\text { REICH } \text { et al. (1998), POORTER } \\
\text { \& ROSE (2005), NIINEMETS } \\
(2006)\end{array}$ \\
\hline $\begin{array}{l}\text { zavarás / } \\
\text { disturbance }\end{array}$ & $\begin{array}{l}\text { életciklus / life cycle } \\
\text { magasság / height } \\
\text { újrahajtási képesség / resprouting capacity }\end{array}$ & $\begin{array}{l}\text { BOND \& MIDGLEY (2001), } \\
\text { MCINTYRE \& LAVOREL (2001), } \\
\text { LOUAULT et al. (2005), } \\
\text { KüHNER \& KLEYER (2008) }\end{array}$ \\
\hline
\end{tabular}

\section{Funkcionális jelleg-csoportok, stratégiák}

A különböző tulajdonság-kombinációk jó alapot nyújthatnak az egyes növényi alkalmazkodási stratégiák vizsgálatához és modellezéséhez is, így a különböző jellegeket kombinálva egységes, átfogó képet kaphatunk a fajok adott élőhelyen alkalmazott stratégiájáról. MACARTHUR \& WILSON (1967) a közgazdaságtanból merített ihletet, és állította fel a ma is alkalmazott $r-K$ modellt. Eszerint a növényi (és állati) stratégiák egy kontinuum mentén helyezkednek el, melynek egyik végletében a kevés utódot reprodukáló fajok állnak, ők az energiát inkább a túlélésbe fektetetik, jó kompetítorok (K-stratégia). A másik véglet a pionír fajokra jellemző, amelyek kevés tartalék tápanyaggal rendelkező nagyszámú utódot hoznak létre, azaz túlélés helyett a szaporodásba invesztálnak ( $r$-stratégia) (bővebben lásd PÁszToR \& OBORNY 2007). 
A növényi stratégiák és a környezeti változók ok-okozati összefüggéseit tárja fel TILMAN (1988) alapműve, amely igen jól foglalja össze a környezeti változók és a növényi tulajdonságok összefüggéseit, illetve a tápanyagokért és fényért folyó kompetíció ökológiai mechanizmusát. A MacArthur \& Wilson-féle elven alapul a GRIME-féle $(1977,1979)$ CSR modell is. Az előbb említett kétféle stratégia (a kompetítor és a ruderális) itt kibővül még egy harmadikkal, a stressztűrővel. A CSR rendszert hosszú ideig fejlesztették, míg végül eljutottak oda, hogy a fajok stratégiáját olyan mérhető növényi jellegekkel lehet következetesen meghatározni, mint a magasság, a magszám, a virágzási idő, levélfelület (HoDGSoN et al. 1999), illetve levél szárazanyag tartalom, levélfelület és fajlagos levélfelület (PIERCE et al. 2013), mivel ezek a jellegek összefüggnek a növény kompetíciós és szaporodási képességével, valamint a fotoszintetikus aktivitással is. A mért értékek alapján a fajok egy háromszög három oldala mentén helyezhetők el, és a három csúcsi pozíción (C-S-R) kívül a háromszög oldalai mentén bármilyen átmeneti pozíciót (stratégiát) is felvehetnek.

A CSR modellhez hasonlóan az LHS modell is egyszerűen mérhető jellegek alapján következtet a fajok ökológiai viselkedésére (WESTOBY 1998), azonban itt csak nyolc konkrét lehetséges stratégia létezik. Az LHS jelentése: leaf (levél), height (magasság), seed (mag), azaz a modellt három alapvető funkcionális jelleg határozza meg: az adott taxon fajlagos levélfelülete (SLA), hajtásmagassága és ezermagtömege (TSW). Ebből a három változóból következtethetünk arra, hogy milyen stratégiát folytat a vizsgált növényfaj. A modellt széles körben alkalmazzák ökológiai kérdések megválaszolására (például GoLODETS et al. 2009, LAUGHLIN et al. 2010, VIOLLE et al. 2011).

A növényi stratégia modellek közül az LLR (Leaf-Life form-Root) modell azért érdekes és különleges, mivel az előbbiektől eltérően nem csak levél, de életforma és gyökér-jellemzők figyelembevételével számolnak stratégia típust a fajokra vonatkozóan (GILLISON 1981, 2002). Ez azért is előnyös, mert így több jelentős adaptációs értékkel bíró tulajdonságot tudunk egy modellbe olvasztani. Nagy hátránya viszont, hogy a gyökérjellegek funkcionális szerepéről kevesebb információ áll rendelkezésünkre más, gyakrabban használt és könnyebben mérhető például levéllel kapcsolatos jellegekhez képest.

\section{Mérési módszerek}

A növényi jellegeken alapuló tanulmányok egyik fontos alappillére az egységes módszertan használata. Ahhoz, hogy nagyobb földrajzi egységet felölelő, vagy több, egymástól független mintavétel eredményét egyesítő tanulmányt végezhessünk, olyan adatokra van szükség, melyek egymással összevethetők. A korai munkák nagy része nem követett egyetlen egységes módszertant, gyakran előfordult, hogy a megválaszolandó problémához igazították a mintavételt. Az utóbbi évtizedben azonban, a meta-analízisek egyre növekvő számának köszönhetően fokozatosan kezd elterjedni a standardizált protokollok alkalmazása.

A ma megjelenő cikkek nagy része már egységes módszertannal dolgozik. A leggyakrabban használt standardizált protokollt a világ vezető növényökológus szakemberei közösen dolgozták ki (CORNELISSEN et al. 2003). Tartalmazza az általánosan használt növényi funkcionális jellegek mérésének módszertanát, illetve rengeteg szakirodalmi példát is közöl jellegeken alapuló vizsgálatokra. Ehhez nagymértékben hasonlít a közelmúltban közölt „új kézikönyv", mely gyakorlatilag a 2003-as javított, bővített változata (PÉREZ-HARGUINDEGUY et al. 2013). Ez az új közlemény a korábbinál jelentősen több jelleg méréséhez ad részletes módszertani leírást, illetve aprólékosabban kitér olyan speciális esetekre, mint például a szélsőségesen árnyékkedvelő vagy szárazságtűrő növények. Továbbá tartalmazza a különböző jellegek mérésekor ajánlott minimális és ideális mintaszámot is. Ebben az összefoglalóban a szerzők nagyobb hangsúlyt fektettek azokra a jellegekre, melyeket ez idáig kevesebbet vizsgáltak. Figyelmet fordítottak az olyan jellegek bemutatására is, melyek fontosak lehetnek a 
kevésbé vizsgált biomok és speciális adaptációjú növényzettel rendelkező élőhelyek esetében, valamint a herbivóriához, gyúlékonysághoz és tápanyagforgalomhoz kötődő jellegekre is.

A módszertani közlemények többsége élő növényi anyag gyűjtését javasolja, emellett azonban - ha a vizsgálni kívánt növényfaj már kipusztult, vagy nagyobb időskálán kívánjuk elvégezni a kísérletet - herbáriumi anyag feldolgozása is lehetséges (QUEENBOROUGH \& PORRAS 2014). A herbáriumokban megőrzött, kiszáradt levelek ugyanannyira jól felhasználhatók fajlagos levélfelület meghatározásra, mint a mesterségesen szárított levelek. Sőt, ha ismerjük az adott növényfaj levelének „zsugorodását” - mely átlagosan 8\%, de növénycsaládonként igen eltérő is lehet (0-30\%) (QUEENBOROUGH \& PoRRAs 2014) - a levél eredeti nedves tömegére is vissza lehet következtetni, így más levéljellegek, mint a szárazanyag tartalom (LDMC) is megbecsülhető.

\section{Adatbázisok}

A növényi funkcionális jellegeken alapuló tanulmányok nagy része azonban nem saját mérésekre hagyatkozik. Egyre gyakrabban nyúlnak nemzetközi adatbázisok anyagához így ezek az adatbázisok is - a növényi jellegeket alkalmazó kutatásokkal szinkronban - gombamód szaporodnak.

Eleinte egy-egy tanulmányhoz kapcsolódóan hoztak létre adatbázisokat, amit később nyilvánossá tettek. Ilyen például a GlopNet adatbázis, mely 2548 fajról tartalmaz levél jelleg adatokat (SLA, levél élettartam, levél vastagság, szövet sűrűség stb.) összesen 175 lelőhelyről a világ minden tájáról (WRIGHT et al. 2004).

Az adatbázis építés egyik legfontosabb kritériuma, hogy egységes módszerekkel mért és egységes mértékegységú adatok kerüljenek bele az adathalmazba. Míg az utóbbi problémát könnyen kiküszöbölhetjük egy egyszerü átváltással, a nem összevethető módszertan alkalmazása használhatatlanná tehet egy adatsort. Olyan helyzettel is találkozhatunk, mikor ugyanazt a funkciót kifejező jelleg más néven szerepel különböző adatbázisokban (vagy éppen ugyanazon az adatbázison belül is). Az SLA, azaz a levél egységnyi száraz tömegére eső levélfelület az egyik leggyakrabban használt levéljelleg, melyet egyes adattáblákban LMA (Leaf Mass per Area), azaz egységnyi levélfelületre eső száraz tömeg formában találunk meg, mely értelemszerűen az SLA reciproka. Mindkét érték a levél szövetének tömörségére és a levél vastagságára utal, ám érdemes odafigyelni az átváltásokra, ha több adatbázisból dolgozunk.

Minden adatbázisnak megvan a maga előnye és erőssége (1. Elektronikus melléklet). A legtöbb megjelenő publikáció a LEDA (például CARBONI et al. 2013), a BiolFlor (például KNAPP et al. 2008) vagy az Ecoflora (például DUPRÉ \& EHRLÉN 2002) adataira épül, melyek különböző földrajzi lefedettségben tartalmazzák az általánosabban használt jellegeket. Ezzel ellentétben olyan speciális adatbázisok is léteznek, melyek egy-egy anatómiai egységre vagy jelleg csoportra fókuszálnak, és ezekről adnak teljes körú információt. Ilyenek többek között a maggal és terjedéssel összefüggő jellegeket tartalmazó SID (LIU et al. 2008) és $\mathrm{D}^{3}$ (HINTZE et al. 2013), a fásszárúakra vonatkozó anatómiai információkat, metszeteket bemutató InsideWood (WHEELER 2011), a gyökér-jellegeket összegző gyökératlasz (KUTSCHERA et al. 1982, 1992a,b), a klonális jellegeket tartalmazó CLO-PLA (KLIMEŠová \& DE BELLO 2009) vagy HARLEY \& HARLEY (1987) mikorrhiza adatbázisa. Újabb keletű kezdeményezés a TRY adatbázis (KATTGE et al. 2011a), mely abban különbözik az eddig említettektől, hogy nem átlagértékeket tartalmaz egy-egy faj egy-egy jellegére, hanem számos különböző, sokszor független mérés eredményét gyűjti össze. A mérések nagy része georeferált pontokhoz van rendelve, illetve magába foglalja a többi nagyobb adatbázis - például a LEDA, a GlopNet, a BiolFlor, a SID és az Ecoflora - adatait is. Hasznos segítség lehet a jelleg attribútumok kereséséhez és az adatbázisok közötti eligazodáshoz a TRY adatbázis honlapján található táblázatos összefoglaló az itt felhasznált adatbázisokról (KATTGE et al. 2011a). 


\section{Összegzés}

Jelen dolgozatban fő célunk volt összefoglalni a növényi funkcionális jellegeket érintő fontosabb alapismereteket, a téma aktualitását is szem előtt tartva. Tárgyaltuk a funkcionális csoportosítás különböző szintjeit, úgymint a klasszikusnak mondható életforma- és növekedési forma kategóriákat. Viszonylag új megközelítés azonban a funkcionális csoportok, típusok, illetve guildek használata, melyek a ma „divatos” funkcionális jellegek alapján osztályozzák a növényeket.

Igyekeztünk definiálni a növényi funkcionális jellegeket, valamint röviden bemutattuk azokat, amelyeket a leggyakrabban alkalmaznak ökológiai kérdések megválaszolására. A jellegeknek különböző típusait ismerjük aszerint, hogy: (i) anatómiailag hol helyezkednek el, (ii) mennyire egyszerűen mérhetők és közvetlen kapcsolatban állnak-e biológiai funkcióval, (iii) minőségi vagy mennyiségi jellegek-e, (iv) hatást vagy választ fejeznek ki. Ezt követően felvázoltuk, hogy az egyes tulajdonság-kombinációkból mely növényi stratégiákra lehet következtetni. A stratégiák segítségével modellezni tudjuk, hogy bizonyos tulajdonságokkal bíró fajok hogyan viselkednek az adott élőhelyen történt változások során, például zavarás vagy antropogén hatások milyen tulajdonságokkal bíró fajoknak kedveznek. (A konkrét környezeti tényezők különböző stratégiájú fajokra és közösségekre gyakorolt hatásáról a későbbiekre tervezett összefoglalókban lesz szó).

Igyekeztünk kiemelni az egységes módszertan használatának szabályait és előnyeit, majd a továbbiakban a nemzetközileg gyakran használt jellegadatbázisokat gyüjtöttük össze, reményeink szerint segítve ezzel a „felhasználók” munkáját.

\section{Köszönetnyilvánítás}

A szerzők ezúton szeretnék kifejezni köszönetüket a kézirat lektorainak, Botta-Dukát Zoltánnak és Kelemen Andrásnak, akik hasznos javaslataikkal és észrevételeikkel segítették a publikáció elkészítését. A kutatás a TÁMOP-4.2.4.A/2-11/1-2012-0001 azonosító számú Nemzeti Kiválóság Program - Hazai hallgatói, illetve kutatói személyi támogatást biztosító rendszer kidolgozása és működtetése konvergencia program című kiemelt projekt keretében zajlott. A projekt az Európai Unió támogatásával, az Európai Szociális Alap társfinanszírozásával valósul meg. A kézirat elkészítését az OTKA K108992 “ Magyarország veszélyeztetett hajtásos növényeinek ritkasága, életmenet-jellemzői és klímaválasza" c. pályázat támogatta.

\section{Irodalom}

Albert Á-J., Kelemen A., Valkó O., Miglécz T., Csecserits A., RéDei T., DeÁK B., Tóthmérész B. \& TöRöK P. (2014): Secondary succession in sandy old-fields: a promising example of spontaneous grassland recovery - Applied Vegetation Science 17: 214-224.

Albert C. H., Thuiller W., Yoccoz N. J., Douzet R., Aubert S. \& Lavorel S. (2010): A multi-trait approach reveals the structure and the relative importance of intra- vs. interspecific variability in plant traits. - Functional Ecology 24: 1192-1201.

BAGI I. (1993): Növényi növekedési formák. I. Elméleti alapok és tudománytörténeti megjegyzések. Botanikai Közlemények 80: 119-128.

BoND W. J. \& MiDGLEY J. J. (2001): Ecology of sprouting in woody plants: the persistence niche. - Trends in Ecology and Evolution 16: 45-51.

Cadotte M. W., Carscadden K. \& Mirotchnicket N. (2011): Beyond species: functional diversity and the maintenance of ecological processes and services. - Journal of Applied Ecology 48: 1079-1087. 
CARboni M., DE Bello F., JANEČEK Š., DoležAl J., HorníK J., LePŠ J., Reitalu T., \& Klimešová J. (2014): Changes in trait divergence and convergence along a productivity gradient in wet meadows. - Agriculture, Ecosystems \& Environment 182: 96-105.

Chave J., Coomes D., Jansen S., Lewis S. L., Swenson N. G. \& Zanne A. E. (2009): Towards a worldwide wood economics spectrum. - Ecology Letters 12: 351-366.

Cornelissen J. H. C., Lavorel S., Garnier E., Díaz S., Buchmann N., Gurvich D. E., Reich P. B., ter Steege H., Morgan H. D., van der Heijden M. G. A. et al. (2003): A handbook of protocols for standardised and easy measurement of plant functional traits worldwide. - Australian Journal of Botany 51: 335-380.

Cornwell W. K., Cornelissen J. H. C., Amatangelo K., DorrepaAl E., Eviner V. T., Godoy O., Hobbie S. E., Hoorens B., Kurokawa H., Pérez-Harguindeguy N. et al. (2008): Plant species traits are the predominant control on litter decomposition rates within biomes worldwide. - Ecology Letters 11: 1065-1071.

Cunningham S. A., Summerhayes B. \& Westoby M. (1999): Evolutionary divergences of leaf structure and chemistry, comparing rainfall and soil nutrient gradients. - Ecological Monographs 69: 569-588.

CSECSERITS A., SzABó R. \& Czúcz B. (2009): Növényi tulajdonságok, tulajdonság-adatbázisok és ezek felhasználása az ökológiai kutatásokban. - Botanikai Közlemények 96: 1-17.

Díaz S., Hodgson J. G., Thompson K., Cabido M., Cornelissen J. H. C., Jalili A., Montserrat-Martí G., Grime J. P., ZARRINKAMAR F., ASRI Y. et al. (2004): The plant traits that drive ecosystems: evidence from three continents. - Journal of Vegetation Science 15: 295-304.

Dupré C. \& EHRLÉn J. (2002): Habitat configuration, species traits and plant distributions. - Journal of Ecology 90: 796-805.

Fenesi A. \& BotTA-DukÁt Z. (2012): Phenotypic divergences induced by different residence time in invasive common ragweeds. - Journal of Plant Ecology 5: 174-181.

FitTER A. H. \& PEAT H. J. (1994): The ecological flora database. - Journal of Ecology 82: 415-425.

Fukami T., Martijn Bezemer T., Mortimer S. R. \& Putten W. H. (2005): Species divergence and trait convergence in experimental plant community assembly. - Ecology Letters 8: 1283-1290.

Garnier E., Lavorel S., Ansquer P., Castro H., Cruz P., Dolezal J., Eriksson O., Fortunel C., Freitas H., GoLODETS C. et al. (2007): Assessing the effects of land-use change on plant traits, communities and ecosystem functioning in grasslands: a standardized methodology and lessons from an application to 11 European sites. - Annals of Botany 99: 967-985.

GAUCHERAND S. \& LAVOREL S. (2007): New method for rapid assessment of the functional composition of herbaceous plant communities. - Austral Ecology 32: 927-936.

Geber M. A. \& GRIFFEn L. R. (2003): Inheritance and natural selection on functional traits. - International Journal of Plant Science 164 (3 Suppl.): S21-S42.

Gillison A. N. (1981): Towards a functional vegetation classification. - In: GiLlison A. N. \& ANDERSON, D. J. (eds), Vegetation Classification in Australia. Commonwealth Scientific and Industrial Research Organization and the Australian National University Press, Canberra, pp. 30-41.

Gillison A. N. (2002): A generic, computer-assisted method for rapid vegetation classification and survey: tropical and temperate case studies. - Conservation Ecology 6: 3.

Gillison A. N. (2013): Plant Functional Types and Traits at the Community, Ecosystem and World Level. - In: van Der MAarel E. \& Franklin J. (eds), Vegetation ecology. John Wiley \& Sons, Chichester, pp. 348-386.

Golodets C., Sternberg M. \& Kigel J. (2009): A community-level test of the leaf-height-seed ecology strategy scheme in relation to grazing conditions. - Journal of Vegetation Science 20: 392-402.

GREEN W. (2009): USDA PLANTS Compilation, Version 1, 09-02-02.

GRIME J. P. (1977): Evidence for the existence of three primary strategies in plants and its relevance to ecological and evolutionary theory. - The American Naturalist 111: 1169-1194.

Grime J. P. (1979): Plant Strategies and Vegetation Processes. - John Wiley \& Sons, Ltd, Chichester, 419 pp.

HARLEY J. L. \& HARLEY E. L. (1987): A check-list of mycorrhiza in the British flora. - New Phytologist 105: 1-102.

Hintze C., HeYdel F., Hoppe C., Cunze S., König A. \& TACKEnBerg O. (2013): D3: the dispersal and diaspore database-baseline data and statistics on seed dispersal. - Perspectives in Plant Ecology, Evolution and Systematics 15: 180-192.

Hodgson J. G., Wilson P. J., Hunt R., Grime J. P. \& Thompson K. (1999): Allocating C-S-R plant functional types: a soft approach to a hard problem. - Oikos 85: 282-294.

Kattge J., Díaz S., Lavorel S., Prentice I. C., Leadley P., Bönisch G., Garnier E., Westoby M., Reich P. B., Wright I. J. et al. (2011a): TRY-a global database of plant traits. - Global Change Biology 17: 2905-2935. 
Kattge J., OGle K., Bönisch G., Díaz S., Lavorel S., Madin J., Nadrowski K., Nöllert S., Sartor K. \& Wirth C. (2011b): A generic structure for plant trait databases. - Methods in Ecology and Evolution 2: 202-213.

Kelemen A., TöröK P., VAlKó O., DeÁK B., Tóth K. \& TóthméRész B. (2015): Both facilitation and limiting similarity shape the species coexistence in dry alkali grasslands. - Ecological Complexity 21: 34-38.

Kirschbaum M. U. (2011): Does enhanced photosynthesis enhance growth? Lessons learned from $\mathrm{CO}_{2}$ enrichment studies. - Plant Physiology 155: 117-124.

Kleyer M., Bekker R. M., Knevel I. C., Bakker J. P., Thompson K., Sonnenschein M., Poschlod P., van Groenendael J. M., Klimes L., KLimesova J. et al. (2008): The LEDA Traitbase: a database of life-history traits of the Northwest European flora. - Journal of Ecology 96: 1266-1274.

KLIMEŠovÁ J. \& De Bello F. (2009): CLO-PLA: the database of clonal and bud bank traits of Central European flora. - Journal of Vegetation Science 20: 511-516.

KLOTZ S., KÜHN I. \& DuRKA W. (2002): BIOLFLOR - Search and Information System on Vascular Plants in Germany. Umweltforschungszentrum Leipzig-Halle GmbH, Leipzig.

KnAPP S., KüHn I., Schweiger O. \& KLOTZ S. (2008): Challenging urban species diversity: contrasting phylogenetic patterns across plant functional groups in Germany. - Ecology Letters 11: 1054-1064.

KutSCHERA L., LichtENEGGER E. \& Sовотік M. (1982): Wurzelatlas mitteleuropäischer Grünlandpflanzen, Band 1: Monocotyledoneae. - Gustav Fischer Verlag, Stuttgart/Jena/New York, 516 pp.

KutSChERA L., LichtenEGGer E. \& SовотіK M. (1992a): Wurzelatlas mitteleuropäischer Grünlandpflanzen, Band 2: Pteridophyta und Dicotyledoneae (Magnoliopsida), Teil 1: Morphologie, Anatomie, Ökologie, Verbreitung, Soziologie, Wirtschaft. - Gustav Fischer Verlag, Stuttgart/Jena/New York, 851 pp.

KutSChERA L., LichtenEGGer E. \& SOBOTiK M., (1992b): Wurzelatlas mitteleuropäischer Grünlandpflanzen, Band 2: Pteridophyta und Dicotyledoneae (Magnoliopsida), Teil 2: Anatomie. - Gustav Fischer Verlag, Stuttgart/Jena/New York, 261.

KÜHNER A. \& KLEYER M. (2008): A parsimonious combination of functional traits predicting plant response to disturbance and soil fertility. - Journal of Vegetation Science 19: 681-692.

LAUGHLIN D. C., LEPPERT J. J., MOORE M. M. \& SiEG C. H. (2010): A multi-trait test of the leaf-height-seed plant strategy scheme with 133 species from a pine forest flora. - Functional Ecology 24: 493-501.

Lavorel S., McIntyre S., LAndsberg J. \& Forbes T. D. A. (1997): Plant functional classifications: from general groups to specific groups based on response to disturbance. - Trends in Ecology and Evolution 12: 474-478.

LAVOREL S. \& GARNIER E. (2002): Predicting changes in community composition and ecosystem functioning from plant traits: revisiting the Holy Grail. - Functional Ecology 16: 545-556.

lavorel S., Díaz S., Cornelissen J. H. C., Garnier E., Harrison S. P., Mcintyre S., Pausas J. G., PérezHaRguindeguy N., Roumet C. \& URCElAy C. (2007): Plant functional types: are we getting any closer to the Holy Grail? - In: Candell J. G., Pataki D. E. \& Pitelka L. F. (eds), Terrestrial ecosystems in a changing world. Springer Berlin Heidelberg, pp. 149-164.

Lavorel S., Gachet S., Sahl A., Colace M.-P., Gaucherand S., Burylo M. \& Bonet R. (2009): A plant functional traits database for the Alps - understanding functional effects of changed grassland management. In: SPHEN E. M. \& KöRnER C. (eds), Data Mining for Global Trends in Mountain Biodiversity. CRC Press, pp. 106-123.

LAWTON J. H. (1999): Are there general laws in ecology? - Oikos 84: 177-192.

LEISHMAN M. R. \& Westoby M. (1994): The role of large seed size in shaded conditions - experimental evidence. - Functional Ecology 8: 205-214.

Liu K., Eastwood R. J., Flynn S., TuRner R. M. \& Stuppy W. H. (2008): Seed information database (release 7.1, May 2008). Available at http://www.kew.org/data/sid.

Louault F., Pillar V. D., Aufrere J., Garnier E. \& Soussana J. F. (2005): Plant traits and functional types in response to reduced disturbance in a semi-natural grassland. - Journal of vegetation Science 16: 151-160.

MacArThuR R. \& Wilson E. O. (1967): The Theory of Island Biogeography. - Princeton University Press, Princeton, 205 pp.

MacArthur R. H. (1972): Geographical Ecology: Patterns in the Distribution of Species. - University Press, Princeton, $275 \mathrm{pp}$.

Mason N. W. H., Mouillot D., LEe W. G. \& Wilson J. B. (2005): Functional richness, functional evenness and functional divergence: the primary components of functional diversity. - Oikos 111: 112-118.

McGill B. J., EnQuist B. J., Weiner E. \& Westoby M. (2006): Rebuilding community ecology from functional traits. - Trends in Ecology and Evolution 21: 178-185. 
MCGilLiVRAY C. W. \& GRIME J. P. (1995): Genome size predicts frost resistance in British herbaceous plants: implication for rates of vegetation response to global warming. - Functional Ecology 9: 320-325.

MCINTYRE S. \& LAVOREL S. (2001): Livestock grazing in subtropical pastures: steps in the analysis of attribute response and plant functional types. - Journal of Ecology 89: 209-226.

MedLYn B. E. \& JARVIS P. G. (1997): Integration of Results from Elevated $\mathrm{CO}_{2}$ Experiments on European Forest Species: The Ecocraft Project. - Forestry Sciences 52: 273-277.

NinEMETS Ü. (2001): Global-scale climatic controls of leaf dry mass per area, density, and thickness in trees and shrubs. - Ecology 82: 453-469.

NinEMETS Ü. (2006): The controversy over traits conferring shade-tolerance in trees: ontogenetic changes revisited. - Journal of Ecology 94: 464-470.

Ordoñez J. C., van Bodegom P. M., Witte J-P. M., Wright I. J., Reich P. B. \& AerTS R. (2009): A global study of relationships between leaf traits, climate and soil measures of nutrient fertility. - Global Ecology and Biogeography 18: 137-149.

Ollivier M., BARALOTO C. \& MARCon E. (2007): A trait database for Guianan rain forest trees permits intraand inter-specific contrasts. - Annals of Forest Science 64: 781-786.

PÁszToR E. \& OBORny B. (szerk.) (2007): Ökológia. - Nemzeti Tankönyvkiadó Zrt, Budapest, 420 pp.

Paula S., Arianoutsou M., Kazanis D., Tavsanoglu Ç., Lloret F., Buhk C., Ojeda F., Luna B., Moreno J. M., Rodrigo A. et al. (2009): Fire-related traits for plant species of the Mediterranean Basin. - Ecology 90: 1420-1420.

PAUla S. \& PAUSAS J. G. (2013): BROT: a plant trait database for Mediterranean Basin species. Version 2013.06. http://www.uv.es/jgpausas/brot.htm

Pavón N., Hernández-Trejo H. \& Rico-Gray V. (2000): Distribution of plant life forms along an altitude gradient in the semi-arid valley of Zapoltitlán, Mexico. - Journal of Vegetation Science 11: 39-42.

Pérez-Harguindeguy N., Díaz S., Garnier E., Lavorel S., Poorter H., Jaureguiberry P., Bret-Harte M. S., Cornwell W. K., Craine J. M., Gurvich D. E. et al. (2013): New handbook for standardised measurement of plant functional traits worldwide. - Australian Journal of Botany 61: 167-234.

Pierce S., Brusa G., VAGGe I. \& CERABolini B. E. L. (2013): Allocating CSR plant functional types: the use of leaf economics and size traits to classify woody and herbaceous vascular plants. - Functional Ecology 27: 1002-1010.

Poorter H., Roumet C. \& CAmpbell B. D. (1996): Interspecific variation in the growth response of plants to elevated $\mathrm{CO}_{2}$ : a search for functional types. - In: KöRnER C. \& BAzZAz F. A. (eds), Carbon Dioxide, Populations, and Communities. Academic Press, San Diego, CA, pp. 375-412.

POORTER H. \& DE JONG R. (1999): A comparison of specific leaf area, chemical composition and leaf construction costs of field plants from 15 habitats differing in productivity. - New Phytologist 143: 163-176.

Poorter L. \& Rose S. A. (2005): Light-dependent changes in the relationship between seed mass and seedling traits: a meta-analysis for rain forest tree species. - Oecologia 142: 378-387.

Poorter H., Nimements U., Walter A., Fiorani F. \& Schurr U. (2010): A method to construct doseresponse curves for a wide range of environmental factors and plant traits by means of a metaanalysis of phenotypic data. - Journal of Experimental Botany 61: 2043-2055.

Poschlod P., Kleyer M., Jackel A. K., Dannemann A. \& TACKenberg O. (2003): BIOPOP - a database of plant traits and Internet application for nature conservation. - Folia Geobotanica 38: 263-271.

QueEnborough S. A. \& Porras C. (2014): Expanding the coverage of plant trait databases - A comparison of specific leaf area derived from fresh and dried leaves. - Plant Ecology \& Diversity 7: 383-388.

RAUNKIÆR C. (1934): The Life Forms of Plants and Statistical Plant Geography. - Clarendon Press, Oxford, $632 \mathrm{pp}$.

Reich P. B., TJoelker M. G., Walters M. B., Vanderklein D. W. \& Buschena C. (1998): Close association of RGR, leaf and root morphology, seed mass and shade tolerance in seedlings of nine boreal tree species grown in high and low light. - Functional Ecology 12: 337-338.

Reich P. B., Wright I. J., Cavander-Bares J., Craine J. M., Oleksyn J., Westoby M. \& Walters M. B. (2003): The evolution of plant functional variation: traits, spectra, and strategies. - International Journal of Plant Sciences 164: 143-164.

Reich P. B. \& OLEKSYN J. (2004): Global patterns of plant leaf N and P in relation to temperature and latitude. - Proceedings of the National Academy of Sciences 101: 11001-11006. 
RUPRECHT E., FENESI A. \& NIJS I. (2014): Are plasticity in functional traits and constancy in performance traits linked with invasiveness? An experimental test comparing invasive and naturalized plant species. - Biological Invasions 16: 1359-1372.

SCHimper A. F. W. (1903): Plant-geography upon a physiological basis. - Eds: Groom P. \& BALFour I. B. The Clarendon Press, Oxford.

Tilman D. (1988): Plant strategies and the dynamics and structure of plant communities. - Monographs in population biology 26. Princeton University Press, New Jersey.

Tilman D. (2001): Functional diversity. - In: LEvin S. A. (ed.), Encyclopedia of Biodiversity 3., Academic Press, San Diego, CA, pp. 109-120.

VAN DER MAAREl E. \& FrankLin J. (eds) (2013): Vegetation ecology. - John Wiley \& Sons, Chichester, 578 pp.

Villéger S., MASON N. W. H. \& Mouillot D. (2008): New multidimensional functional diversity indices for a multifaceted framework in functional ecology. - Ecology 89: 2290-2301.

Violle C., Navas M.-L., Vile D., Kazakou E., Fortunel C., Hummel I. \& Garnier E. (2007): Let the concept of trait be functional! - Oikos 116: 882-892.

Violle C., Bonis A., Plantegenest M., Cudennec C., Damgaard C., Marion B., Le Coeur D. \& Bouzillé J. B. (2011): Plant functional traits capture species richness variations along a flooding gradient. - Oikos 120: 389-398.

WARMING E. (1884): Om Skudbygning, Overvintring og Foryngelse [On shoot architecture, perennation and rejuvenation]. - Naturhistorisk Forenings Festskrift: 1-105.

WARMING E. (1909): Oecology of plants: an introduction to the study of plant communities. - Oxford University Press, London, $422 \mathrm{pp}$.

WESTOBY M. (1998): A leaf-height-seed (LHS) plant ecology strategy scheme. - Plant and Soil 199: 213-227.

WHEELER E. A. (2011): InsideWood - a web resource for hardwood anatomy. - IAWA Journal 32: 199-211.

Wright I. J., Reich P. B., Westoby M., Ackerly D. D., Baruch Z., Bongers F., Cavender-Bares J., Chapin T., Cornelissen J. H. C., Diemer M. et al. (2004): The worldwide leaf economics spectrum. - Nature 428: 821-827.

Zanne A. E., Lopez-Gonzalez G., Coomes D. A., Ilic J., Jansen S., Lewis S. L., Miller R. B., Swenson N. G., Wiemann M. C. \& Chave J. (2009): Data from: Towards a worldwide wood economics spectrum. Dryad Digital Repository.

\section{Hivatkozott világháló oldalak:}

[1] LEDA. http://www.leda-traitbase.org/ (Jelenleg nem hozzáférhető)

[2] ECological DATABASE OF THE BRiTiSH IsLES. http://ecoflora.co.uk/ (Hozzáférés: 2015. 08. 24.)

[3] System BiolFloR. http://www2.ufz.de/biolflor/index.jsp (Hozzáférés: 2015. 08. 24.)

[4] BIOPOP: BIOLOGICAL PARAMETERS OF POPULATION MANAGEMENT IN PLANTS. http://www.floraweb.de/biopop/biopop_en.htm (Hozzáférés: 2015. 08. 24.)

[5] Biological Traits of VAscular Plants: A database. http://www.unioldenburg.de/en/biology/landeco/download-and-service/databases/biological-traits-of-vascularplants/ (Hozzáférés: 2015. 08. 24.)

[6] SEEd InfoRmation DatabaSE. http://data.kew.org/sid/ (Hozzáférés: 2015. 08. 24.)

[7] DisPERSAL DiASPORE DATABASE http://www.seed-dispersal.info/ (Hozzáférés: 2015. 10. 04)

[8] InSIDEWood. http://insidewood.lib.ncsu.edu/welcome (Hozzáférés: 2015. 08. 24.)

[9] DRYAD DigitAL REPOSITORY. http://datadryad.org/pages/organization (Hozzáférés: 2015. 08. 24.)

[10] CLO-PLA http://clopla.butbn.cas.cz/ (Hozzáférés: 2015. 11. 02.)

[11] PLANTSDATA. http://bricol.net/downloads/data/PLANTSdatabase/ (Hozzáférés: 2015. 08. 24.)

[12] BROT: PLANT TRAIT DATABASE FOR MEDITERRANEAN BASIN SPECIES. http://www.uv.es/jgpausas/brot.htm (Hozzáférés: 2015. 08. 24.)

[13] Guiana SPEcies Database. http://www.ecofog.gf/Mariwenn/ (Hozzáférés: 2015. 08. 24.)

[14] GLOPNET - GLOBAL PlANT TRAIT NETWORK. http://bio.mq.edu.au/ iwright/glopian.htm (Hozzáférés: 2015. 08. 24.)

[15] TRY Plant TRAit DataBaSE. https://www.try-db.org/TryWeb/Home.php (Hozzáférés: 2015. 08. 24.)

Beérkezett / received: 2015. 09. 04. • Elfogadva / accepted: 2015. 11. 04. 


\section{E. VojTKó Anna \& LUKács Balázs András (2015):}

Növényi jellegek és alkalmazásuk növényökológiai kutatásokban I.: Történeti áttekintés, jelleg típusok, módszertan és adatbázisok

Plant functional traits and their application in ecological research I.: History, traits, methodologies and databases

Kitaibelia 20 (2): 286-299.

DOI:10.17542/kit.20.286

1. Elektronikus melléklet - Ismertebb jellegadatbázisok. Jelmagyarázat: $\mathrm{T}$ - adatok típusa, 1 - faj-jelleg mátrix, 2 - jellegek a környezeti vagy kísérletes körülményekkel együtt, 3 - Fajon belüli jelleg variabilitás a környezeti vagy kísérletes körülményekkel együtt; $\mathrm{H}$ - adatok hozzáférhetősége, :) teljes körű szabad hozzáférés, $:$ nincs szabad hozzáférés (az adatok regisztráció után megvásárolhatók vagy társszerzőség fejében igényelhetők), : * honlap nem ismert (KATTGE et al. 2011b alapján kibővítve).

Electronic Appendix 1. - Well-known trait databases. Notations: T - data type, 1 - species-trait matrix, 2 traits and environmental factors or experimental context, 3 - intraspecific variability and trait-trait correlations in an environmental or experimental context; $\mathrm{H}$ - availability of data, () freely available, : available only for registered customers or for co-authorship. : $:$ webpage is unknown (expanded after KATTGE et al. 2011b). 


\begin{tabular}{|c|c|c|c|c|c|c|}
\hline Adatbázis / Database & $\mathbf{T}$ & Hivatkozás / Reference & Web & $\mathbf{H}$ & $\begin{array}{l}\text { Fajok és jellegek / } \\
\text { Species and traits }\end{array}$ & $\begin{array}{l}\text { Jellemzés és specialitások / } \\
\text { Characteristics and specialties }\end{array}$ \\
\hline LEDA & $1 \#$ & KLEYER et al. (2008) & {$[1]$} & : & & Főként észak- és nyugat-európai fajokat tartalmaz. \\
\hline Ecoflora & 1 & FITTER \& PEAT (1994) & {$[2]$} & (:) & $\begin{array}{l}3842 \text { faj, több mint } 130 \text { ökológiai és } \\
\text { morfológiai jelleg }\end{array}$ & $\begin{array}{l}\text { Jellegeken kívül tartalmaz elterjedési térképeket } \\
\text { (Nagy-Britannia), herbáriumi példányokat, } \\
\text { és fotókat is }\end{array}$ \\
\hline BiolFlor & 1 & KLOTz et al. (2002) & {$[3]$} & : & $\begin{array}{l}\text { Közel } 3660 \text { faj, több mint } 60 \\
\text { funkcionális jelleg }\end{array}$ & \\
\hline BIOPOP & 1 & Poschlod et al. (2003) & [4] & $:$ & Közép-Európa flórája & $\begin{array}{l}\text { Segédleteket tartalmaz különböző kezelési vagy } \\
\text { természetvédelmi problémák esetére }\end{array}$ \\
\hline SID & 1 & $\begin{array}{l}\text { Liu et al. (2008), } \\
\text { Royal Botanic GARDENS KeW (2015) }\end{array}$ & [6] & :) & Magjellegek és terjedés & Több taxomóniai szinten is kereshető \\
\hline D3 & 1 & HINTZE et al. 2013 & [7] & ;) & Több, mint 5000 taxon & Maggal és terjedéssel kapcsolatos jellegek \\
\hline InsideWood & 1 & WHEELER (2011) & {$[8]$} & (:) & $\begin{array}{l}\text { Fosszilis és recens kétszikű fafajok, } \\
200 \text { növénycsaládból, } 40000 \text { fotó }\end{array}$ & $\begin{array}{c}\text { Anatómiai információ irodalmi adatok és saját } \\
\text { megfigyelések alapján }\end{array}$ \\
\hline Wood Density & 1 & CHAVE et al. (2009), ZANNE et al. (2009) & [9] & ;) & & A weboldal tartalmazza a kapcsolódó publikációkat \\
\hline CLO-PLA & 1 & KLIMEŠovÁ \& De BELLo (2009) & {$[10]$} & (:) & Közel 3000 közép-európai faj & $\begin{array}{c}\text { A klonális növekedéssel és a vegetatív szaporodással } \\
\text { kapcsolatos jellegek irodalmi adatok és saját terepi } \\
\text { megfigyelések alapján }\end{array}$ \\
\hline PLANTSdata & 1 & GREEN (2009) & [11] & (:) & & \\
\hline BROT & 1 & PAUla et al. (2009), PAULA \& PAUSAS (2013) & [12] & :) & $\begin{array}{l}8263 \text { rekord, } 952 \text { taxon, } 14 \text { jelleg, } 301 \\
\text { irodalmi forrásból }\end{array}$ & Mediterrán flóra \\
\hline ECOCRAFT & 2 & MEDLYN \& JARVIS (1997) & & 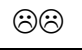 & & Fás szárúak és környezetük kapcsolata \\
\hline MARIWENN & 2 & OLLIVIER et al. (2007) & [13] & : & $\begin{array}{l}\text { Guyana fafajaira vonatkozó } \\
\text { információk }\end{array}$ & Üvegházi kísérletek eredményeit is tartalmazza \\
\hline ALTA & 2 & LAVOREL et al. (2009) & & 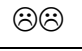 & & Az Alpok flórája, gyepgazdálkodási szempontú \\
\hline VISTA & 2 & GARNIER et al. (2007) & & 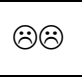 & $\begin{array}{c}11 \text { európai élőhely fajai, } 16 \\
\text { funkcionális jelleg }\end{array}$ & \\
\hline ArtDeco & 2 & Cornwell et al. (2008) & & 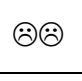 & $\begin{array}{c}818 \text { faj, levéljellegek } 66 \text { kísérletből } \\
\text { világszerte }\end{array}$ & \\
\hline GlopNet & 3 & WRIGHT et al. (2004) & [14] & $: ;$ & Levéljellegek, 2548 faj 175 lelőhelyről, & \\
\hline CORDOBASE & 3 & DíAz et al. (2004) & & $: \circ$ & 640 taxon, 12 jelleg & \\
\hline Meta-Phenomics & 3 & POORTER et al. (2010) & & $: \otimes$ & 800 faj, 1000 kísérlet eredménye & \\
\hline FET & 3 & KATTGE et al. $(2011 b)$ & & $\theta:$ & & \\
\hline TRY & 3 & KATTGE et al. $(2011 a)$ & {$[15]$} & : & $\begin{array}{l}5 \text { millió adat, } 1100 \text { jelleg, } 100000 \\
\text { növényfaj } 2,2 \text { millió egyede, } 12000 \\
\text { lelőhely (geo-referált) }\end{array}$ & $\begin{array}{l}\text { Magába foglalja többek között a LEDA, a GlopNet, } \\
\text { a BiolFlor, a SID és az EcoFlora adatait is }\end{array}$ \\
\hline
\end{tabular}

\# Ugyan tartalmaz egyedi mérési adatokat is, amikből következtetni lehet az adott jelleg variabilitására, környezeti adatokat nem tartalmaz 